\title{
PEDOLOGICAL STUDIES ON THE SOILS OF WADI EL-ASYUTI, EASTERN DESERT, EGYPT
}

\author{
Samy A. Abd-Allah \\ Soils, Water and Environ. Res. Institute. Agric. Res. Center, Giza, Egypt
}

\begin{abstract}
:
Wadi El-Asyuti is encompassing promising areas for the future projects of agricultural utilization, however, its soils are occupied an area of the Eastern Desert of Egypt. According to the aerial photo-interpretation technique, the identified main landforms could be assigned to five units, i.e., Wadi plain, Wadi bottom, Rubble terraces, Alluvial fan, River terraces and Rocky area. The developed soils on these units were investigated throughout ten representative soil profiles. The obtained results indicated that the studied soils are characterized by texture class varies of sandy-silty clay loam, $\mathrm{CaCO}_{3}$ content of 1.2-37.7 \% and organic matter content of 0.05-0.61\%. Also, the soil salinity of the investigated soils ranged between non-saline to extremely-saline, soil $\mathrm{pH}$ tended to alkaline side, and soluble cations were generally categorized in an ascending order of $\mathrm{Ca}^{++}>\mathrm{Na}^{-}>\mathrm{Mg}^{++}>\mathrm{K}^{+}$vs soluble anions of $\mathrm{SO}_{4}^{--} \geq \mathrm{Cl}$, which were alternatively dominated and both exceed soluble $\mathrm{HCO}_{3}{ }^{-}$.

Soils of coarse texture class have the highest soil bulk density values (Wadi plain and Rubble terraces soils), while the relatively fine texture soils (Alluvial fan and River terraces soils) have the lowest ones. On the contrary, soil total porosity values exhibited an opposite trend, the highest values were recorded in case of the fine soil texture and tended to decrease with increasing coarseness of soil texture. Also, the greatest values of hydraulic conductivity are associated with the soils of coarse texture class, and then decreased in the fine textured soils of alluvial fan and River terraces soils. In addition, available soil moisture range coincides very well with textural variations among soil profile layers. Moreover, the CEC values are more related with soil texture class, besides an exchangeable sodium percentage indicates that the studied soils are non-sodic.

Statistical size parameters revealed that the studied soil sediments of Wadi El-Asyuti are mostly transported and deposited through an aqueous environment, and locally combined action of aqueous-aeolian media. With regard to the mineralogical composition of the studied soils, the obtained data showed that heavy minerals are detected as opaques, pyroxenes and amphiboles in high amounts. Also, the ultra stable minerals of zircon, garnet and rutile are present in relatively moderate amounts, while the remaining ones are detected in less pronounced amounts. The ratios of ultra stable minerals and weathering values indicate that soils of Wadi El-Asyuti are formed of either multi-origin or multi-depositional regime, due to the heterogeneity of the parent materials prior to inception to geogenetic weathering or resulted in from the geochemical weathering prevailed in the source sediments.
\end{abstract}

Key words: Soils of Wadi El-Asyuti, Statistical parameters, Eastern Desert Wadies, Ultra stable minerals \& their ratios, weathering values.

Fayoum J. Agric. Res. \& Dev., Vol.24, No.1, January, 2010 
INTRODUCTION:

Egypt is suffering greatly from the gradual attack of building and other industrial establishments on the cultivated soils. Thousands of feddans of the very fertile agricultural lands are being lost every year, which consequently lowers the agricultural production and badly affects the national exhausted-economy. One of the best solutions for that problem is to encourage youth graduates to reclaim and occupy cultivable areas on both sides of the Nile Valley.

The Eastern Desert extends from the Nile Valley, in the west, to the Gulf of Suez and Red Sea, in the East. It occupies about $21 \%$ of Egypt's total area. The Eastern desert is also richness with soil and water resources and intensively dissected by Valleys and ravines. The surface of the Eastern Desert is intensively dissected by a great number of dry drainage vallies, which form two types. The eastward type drainages to the Red Sea by numerous independent and short wadies, while the westward type drainages to the Nile Valley, through a few number of great trunk channels such as Wadi Tarafa, El-Asyuti, Qena and Allaqui.

Said (1962) and Abu Al-Izz (1971) reported that Wadi El-Asyuti is the greatest Wadi in the Eastern Desert and runs over the surface of limestone plateau, and flows toward the River Nile in the west at Asyut city. The watershed of this wadi lies at the high cliffs of the Eocene plateau at Khashm Umm omeiyid (787m.a.s.L.), its water flows about $150 \mathrm{~km}$ driving in its front great amounts cobbles, conglomerates, gravels, sand and carbonates.

According to the High Dam Soil Survey Project (HDSS, 1964), the soils of Wadi El-Asyti could be evaluated according to their soil potentiality classes for irrigated agriculture. Also, Land Master Plant (1986) studied the soils of several transects across the soils of Wadi El-Asyti to execute soil survey, which was based on Aerial photo and Landsat Images as well as the soils were classified according to USDA (1975).

The goal of this study is to evaluate the physical, chemical and mineralogical characteristics of the soils of Wadi El-Asyuti in order to be used as a scientific guide for soil reclamation for increasing the arable area to overcome the crucial situation of the fast increasing population.

\section{MATERIAL AND METHODS:}

To achieve the aforementioned target, the used data that cover the studied area (Figure, 1) are geometrically corrected raster layers of Aerial photos data by using the Aerial Photo-interpretation technique according to Gossen (1967) for delineating the physiographic and urban polygons by the visual interpretation resulting in a stereovision information system composite for the selected terrain as a soil map. According to the aerial photo-interpretation technique, the identified main landforms could be assigned to five units, i.e., Wadi plain, Wadi bottom, Rubble terraces, Alluvial fan, River terraces and Rocky area.

Field truth was performed for review the soil mapping units (landform units) and to identify the boundaries between them as well as the main morphological characteristics at the representative ten soil sites using the soil described items following the guidelines undertaken after FAO (1990). Soil

Fayoum J. Agric. Res. \& Dev., Vol.24, No.1, January, 2010 
samples were collected from the subsequent layers of each profile, and then dried, sieved through a $2 \mathrm{~mm}$ sieve and kept for the different soil analyses under investigation.

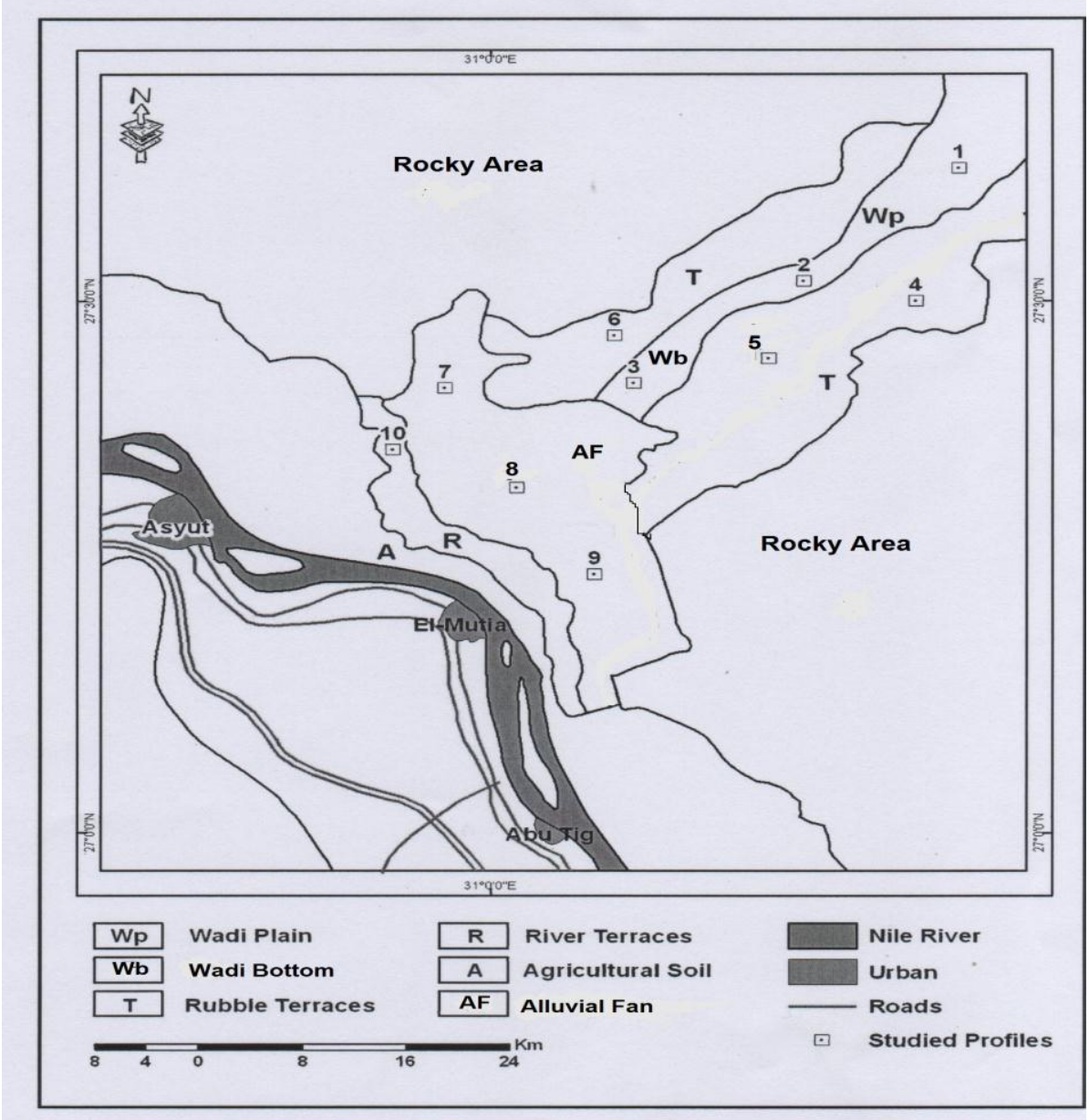

Fig. (1): Physiographic units and the studied soil profiles.

Particle size distribution was carried out according to the International Method (Piper. 1950). Soil bulk density was determined using undisturbed soil samples (Vomocil, 1965). Moisture retention values were determined using the pressure cooker at 0.1 and 0.33 atm as well as the pressure membrane apparatus at $15 \mathrm{~atm}$. Hydraulic for undisturbed soil samples was determined (Richards, 1954). Total porosity was calculated from the obtained values of bulk density with assumption that the real density of the studied soils is $2.65 \mathrm{~g} \mathrm{~cm}^{-3}$ (James, 1965).

$\mathrm{CaCO}_{3}$ content was estimated using the Collin's Calcimeter (Piper, 1950). Electrical conductivity (ECe) and soluble ions were determined in the soil paste extract (Jackson, 1967). Soil pH was measured in the soil paste (Jackson, 1967). Cation exchange capacity and exchangeable sodium were determined according to the method described by Tucker (1954). The cumulative curves were drawn on semi-log paper using the phinotation of the equations of Pettijohn (1957) to identify the statistical size parameters of median, sorting and skeweness.

Fayoum J. Agric. Res. \& Dev., Vol.24, No.1, January, 2010 
Mineralogical analysis of the sand fraction sized 125-63u after the ordinary pretreatments (Jackson, 1965) was separated from each sample by wet sieving, cleaned up and further differentiated into heavy and light minerals using Bromoform (Sp. Gr. 2.87 \pm 0.02) as outlined by Brewer (1964). Heavy minerals were washed, dried and mounted on glass slides using Canda Balsam. The minerals were examined under the polarized microscope, 500 grains in each case were counted under investigation to minimize the relative error.

\section{RESULTS AND DISCUSSION: \\ 1- Morphological and physico-chemical properties:}

Morphological features and physico-chemical properties of the representative soil profiles are shown in Tables (1,2 and 3). From the obtained data, it could be assigned a general view about the soil characteristics of the identified physiographic units, as follows:

\section{a. Soils of Wadi plain and bottom:}

The unit (Wadi) represents a natural drainage valley that may have the shape of elongate deeply-incised depressions or gullies. This unit (Wadi) could be differentiated into two landforms, i.e.,Wadi plain and Wadi bottom. Wadi plain includes the area without stream beds, which are occasionally flooded by run-off water from adjacent elevated areas, while Wadi bottom represents the lower parts of the natural drainage pathways showing one or more stream beds. These Wadi units are represented by profile Nos. 1, 2 and 3, however, the obtained data in Table (2) show that soil texture lies in the relatively coarse grade of sandy-loamy sand. Also, a pronounced $\mathrm{CaCO}_{3}$ content of 12.5-20.9 \% with an irregular distribution pattern with depth was occurred. An extremely low content of organic matter $(0.02-0.15 \%)$ was detected owing to the prevailing aridity in the region and its scattered natural vegetation. Accordingly, the CEC is rather relatively low due to the nature of relatively coarse texture grade, where its values fluctuate between 4.3 and $7.8 \mathrm{c}$ molc $\mathrm{kg}^{-1}$ soil as well as ESP value ranged $3.4-11.2 \%$ indicating non-sodic soils, as shown in Table (2).

Soil bulk density depends on number of factors including soil texture packing, organic matter content, soluble salts, exchangeable cations and soil depth (Baver, 1963). According to this basis, soil bulk density value is relatively high and ranged 1.55-182 $\mathrm{g} \mathrm{cm}^{-3}$. Also, soil total porosity, which is an index of the relative volume of pores in the soil, showed an opposite trend for soil bulk density, and then its values varied from 18.9 to $45.5 \%$. Hydraulic conductivity is an important parameter for planning the design systems of irrigation and drainage as well as leaching operations of saline and sodic soils. In addition, it measures the rate of downward movement of water by gravity, however, the values of hydraulic conductivity ranged from 7.5 to $22.8 \mathrm{~cm} \mathrm{~h}^{-1}$ (Table 3).

Moisture characteristic is a useful tool that manifests pore space distribution and soil-water energy relation. Also, available moisture is a stable property that is considered characteristic for soil type. Data in Table (3) dictated the percentages of retained moisture as an available range. From the data presented, it can be observed that available moisture content in the soil tended to decrease in soils of Wadi plain and bottom, which are represented by soil profile Nos. 1. 2 and 3 .

Fayoum J. Agric. Res. \& Dev., Vol.24, No.1, January, 2010 
PEDOLOGICAL STUDIES ON THE SOILS OF WADI EL-ASYUTI,... 110

Table (1): Morphological description of the studied soil profiles.

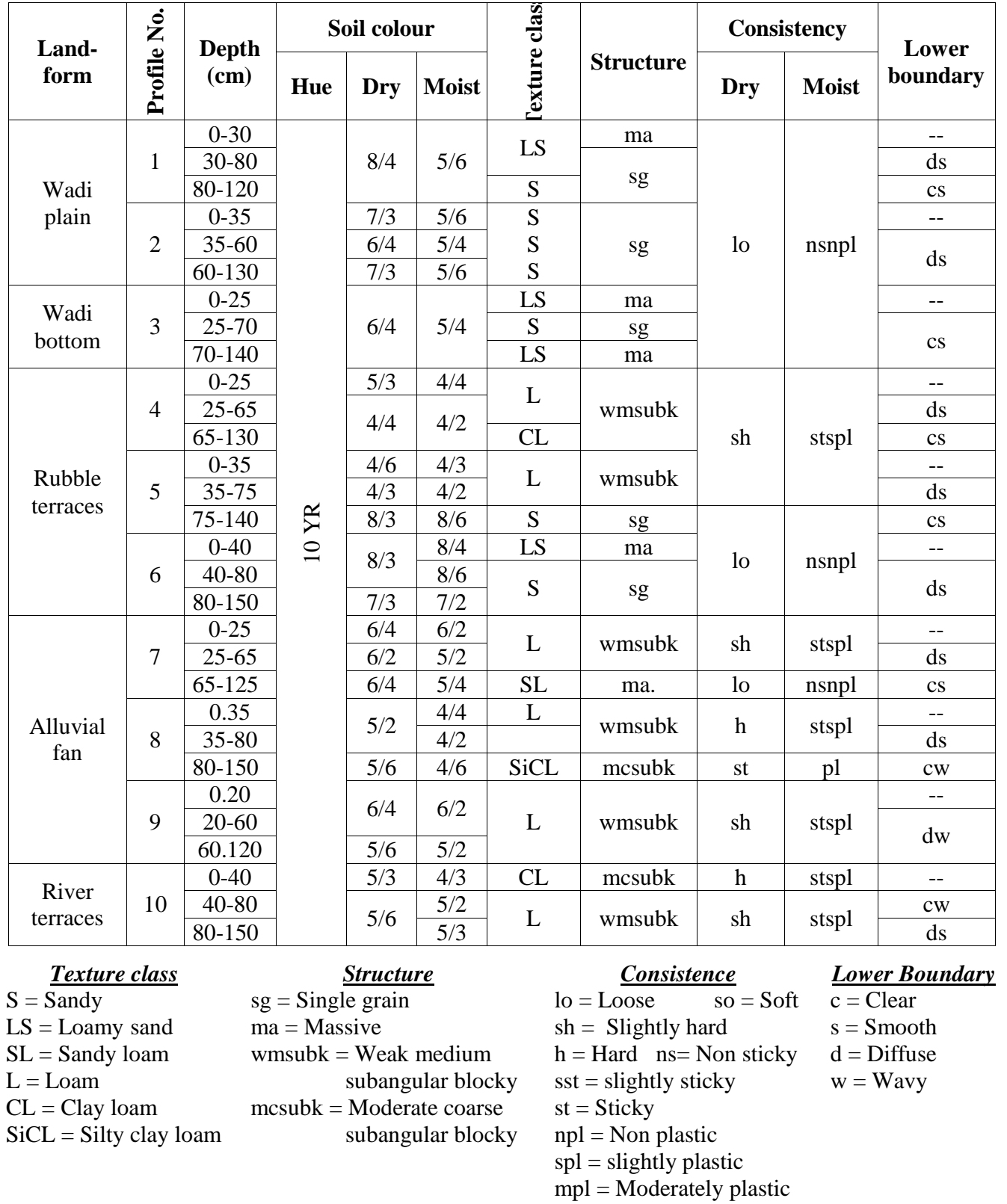

This behaviour is more attributed to that these soils are poorer in the finer fractions, and then the values of available moisture range are mostly lower, i.e., 4.70-9.55\%. Such low available soil moisture content is also rendered to low energy of water retention on the low specific surface of the coarse particles of these soil sediments. In contrast, it is quite clear that the retained moisture for coarse textured soils of these units of Wadi landforms is slightly higher than those of quartzitic in nature, this is due to coatings of colloidal carbonates and free iron oxides which retain more water relative to uncoated quartz grains.

Fayoum J. Agric. Res. \& Dev., Vol.24, No.1, January, 2010 
Samy A. Abd-Allah

Table (2): Particle size distribution, $\mathrm{CaCO}_{3}$, organic matter, $\mathrm{CEC}$ and $\mathrm{ESP}$ of the studied soil profiles.

\begin{tabular}{|c|c|c|c|c|c|c|c|c|c|c|c|}
\hline \multirow{2}{*}{$\begin{array}{l}\text { Land- } \\
\text { form }\end{array}$} & \multirow{2}{*}{ 递 } & \multirow{2}{*}{ 竞 } & \multicolumn{4}{|c|}{ Particle size distribution $\%$} & \multirow{2}{*}{ 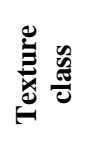 } & \multirow{2}{*}{$\mathrm{CaCO}_{3} \%$} & \multirow{2}{*}{$\begin{array}{c}\text { Organic } \\
\text { matter } \\
\%\end{array}$} & \multirow{2}{*}{$\begin{array}{c}\text { CEC } \\
\text { (c molc } \\
\mathrm{kg}^{-1} \\
\text { soil) }\end{array}$} & \multirow{2}{*}{ ESP } \\
\hline & & & $\begin{array}{c}\text { Coarse } \\
\text { sand }\end{array}$ & $\begin{array}{l}\text { Fine } \\
\text { sand }\end{array}$ & Silt & Clay & & & & & \\
\hline \multirow{6}{*}{$\begin{array}{l}\text { Wadi } \\
\text { plain }\end{array}$} & \multirow{3}{*}{1} & $0-30$ & 27.4 & 51.2 & 7.7 & 6.3 & \multirow{2}{*}{ LS } & 17.20 & 0.14 & 7.80 & 3.40 \\
\hline & & $30-80$ & 79.8 & 38.4 & 8.7 & 6.4 & & 22.30 & 0.05 & 4.90 & 9.33 \\
\hline & & $80-120$ & 87.6 & 6.3 & 1.5 & 4.6 & \multirow{4}{*}{$\mathrm{S}$} & 16.50 & 0.05 & 5.90 & 11.20 \\
\hline & \multirow{3}{*}{2} & $0-35$ & 80.8 & 15.8 & 0.6 & 2.8 & & 20.50 & 0.12 & 4.50 & 8.40 \\
\hline & & $35-60$ & 42.7 & 52.6 & 1.7 & 3.0 & & 20.90 & 0.02 & 4.30 & 5.40 \\
\hline & & $60-130$ & 37.6 & 59.9 & 0.9 & 1.6 & & 15.30 & 0.03 & 5.20 & 6.80 \\
\hline \multirow{3}{*}{$\begin{array}{l}\text { Wadi } \\
\text { bottom }\end{array}$} & \multirow{3}{*}{3} & $0-25$ & 34.4 & 52.1 & 3.8 & 9.7 & LS & 18.60 & 0.15 & 6.20 & 8.60 \\
\hline & & $25-70$ & 64.0 & 35.0 & 3.6 & 4.4 & $\mathrm{~S}$ & 12.50 & 0.02 & 6.60 & 8.20 \\
\hline & & $70-140$ & 61.4 & 27.6 & 4.8 & 6.2 & LS & 19.80 & 0.02 & 5.50 & 8.10 \\
\hline \multirow{9}{*}{$\begin{array}{l}\text { Rubble } \\
\text { terraces }\end{array}$} & \multirow{3}{*}{4} & $0-25$ & 19.2 & 27.0 & 36.0 & 17.8 & \multirow{2}{*}{$\mathrm{L}$} & 22.70 & 0.30 & 15.30 & 4.60 \\
\hline & & $25-65$ & 16.0 & 23.8 & 34.5 & 25.9 & & 3.20 & 0.21 & 18.50 & 8.20 \\
\hline & & $65-130$ & 11.0 & 24.7 & 35.6 & 28.7 & $\mathrm{CL}$ & 1.20 & 0.11 & 20.60 & 13.50 \\
\hline & \multirow{3}{*}{5} & $0-35$ & 18.8 & 20.3 & 40.9 & 20.9 & \multirow{2}{*}{$\mathrm{L}$} & 22.10 & 0.21 & 17.50 & 3.80 \\
\hline & & $35-75$ & 12.0 & 22.1 & 40.1 & 25.8 & & 28.10 & 0.20 & 19.30 & 3.50 \\
\hline & & $75-140$ & 59.1 & 31.9 & 3.6 & 5.4 & $S$ & 7.20 & 0.10 & 5.20 & 3.80 \\
\hline & \multirow{3}{*}{6} & $0-40$ & 50.2 & 36.9 & 7.3 & 5.6 & LS & 6.70 & 0.10 & 5.20 & 3.50 \\
\hline & & $40-80$ & 78.1 & 12.4 & 4.6 & 4.9 & \multirow[t]{2}{*}{$\mathrm{S}$} & 2.50 & 0.13 & 4.60 & 8.20 \\
\hline & & $80-150$ & 78.6 & 15.4 & 1.8 & 4.2 & & 4.60 & 0.13 & 4.40 & 6.30 \\
\hline \multirow{9}{*}{$\begin{array}{l}\text { Alluvial } \\
\text { fan }\end{array}$} & \multirow{3}{*}{7} & $0-25$ & 16.2 & 22.3 & 39.9 & 21.6 & \multirow[t]{2}{*}{$\mathrm{L}$} & 28.60 & 0.90 & 14.20 & 4.50 \\
\hline & & $25-65$ & 3.8 & 28.7 & 44.9 & 22.6 & & 29.80 & 0.50 & 15.10 & 2.90 \\
\hline & & $65-125$ & 10.6 & 64.2 & 16.5 & 8.7 & SL & 20.20 & 0.40 & 7.10 & 5.30 \\
\hline & \multirow{3}{*}{8} & 0.35 & 13.6 & 22.1 & 39.1 & 25.2 & & 9.90 & 0.80 & 20.30 & 12.10 \\
\hline & & $35-80$ & 7.8 & 12.9 & 43.4 & 36.0 & $\mathrm{~L}$ & 2.10 & 0.40 & 25.90 & 14.50 \\
\hline & & $80-150$ & 5.1 & 5.7 & 50.8 & 38.4 & SiCL & 2.60 & 0.30 & 32.50 & 10.30 \\
\hline & & 0.20 & 17.5 & 11.1 & 46.3 & 25.1 & & 12.40 & 0.90 & 17.90 & 4.50 \\
\hline & 9 & $20-60$ & 5.8 & 21.3 & 47.9 & 25.0 & $\mathrm{~L}$ & 39.50 & 0.30 & 16.90 & 5.20 \\
\hline & & 60.120 & 21.0 & 23.9 & 34.0 & 21.1 & & 37.70 & 0.30 & 15.50 & 2.90 \\
\hline & & $0-40$ & 0.7 & 19.1 & 45.2 & 32.4 & $\mathrm{CL}$ & 30.20 & 0.70 & 15.70 & 4.50 \\
\hline River & 10 & $40-80$ & 12.7 & 28.1 & 36.2 & 23.0 & & 13.90 & 0.57 & 12.60 & 3.90 \\
\hline & & $80-150$ & 16.2 & 22.4 & 36.8 & 24.6 & $\mathrm{~L}$ & 28.20 & 0.34 & 13.50 & 5.30 \\
\hline
\end{tabular}

$\mathrm{S}=$ sandy, $\mathrm{LS}=$ Loamy sand, $\mathrm{SL}=$ Sandy loam, $\mathrm{L}=$ Loamy, $\mathrm{CL}=$ Clay loam, $\mathrm{SiCL}=$ silty clay loam

Concerning the chemical analysis of either soil paste or its extract, the obtained data in Table (4) showed that soil $\mathrm{pH}$ values range from 7.8 to 8.2, indicating that the soils are slightly to moderately alkaline. Also, the ECe values of the representative profiles reveale that soil salinity varied from non-saline to strongly saline, where ECe value ranged 2.35-37.20 $\mathrm{dSm}^{-1}$. The cationic composition of soluble salts is mostly dominated by $\mathrm{Ca}^{++}$followed by $\mathrm{Na}^{+}$and $\mathrm{Mg}^{++}$, while $\mathrm{K}^{+}$constitutes the least soluble cation. Soluble anions are characterized by the dominance of $\mathrm{Cl}^{-}$followed by $\mathrm{SO}_{4}{ }^{2-}$ and $\mathrm{HCO}_{3}{ }^{-}$, except for profile 2 which $\mathrm{SO}_{4}{ }^{2-}$ exceeds $\mathrm{Cl}^{-}$.

Fayoum J. Agric. Res. \& Dev., Vol.24, No.1, January, 2010 
PEDOLOGICAL STUDIES ON THE SOILS OF WADI EL-ASYUTI,... 112

Table (3): Bulk density, total porosity and hydraulic conductivity of the studied soil profiles.

\begin{tabular}{|c|c|c|c|c|c|c|}
\hline Land-form & $\stackrel{0}{0}$ & $\begin{array}{c}\text { Depth } \\
\text { (cm) }\end{array}$ & $\begin{array}{c}\text { Bulk } \\
\text { density } \\
\left(\mathrm{g} / \mathrm{cm}^{3}\right)\end{array}$ & $\begin{array}{c}\text { Total } \\
\text { porosity } \\
\%\end{array}$ & $\begin{array}{c}\text { Hydraulic } \\
\text { conductivity } \\
(\mathrm{cm} / \mathrm{h})\end{array}$ & $\begin{array}{c}\text { Available } \\
\text { water range } \\
\%\end{array}$ \\
\hline \multirow{6}{*}{ Wadi plain } & \multirow{3}{*}{1} & $0-30$ & 1.82 & 40.5 & 15.20 & 7.30 \\
\hline & & $30-80$ & 1.70 & 41.8 & 10.90 & 6.00 \\
\hline & & $80-120$ & 1.55 & 45.5 & 7.50 & 5.97 \\
\hline & \multirow{3}{*}{2} & $0-35$ & 1.62 & 40.2 & 10.50 & 7.28 \\
\hline & & $35-60$ & 1.80 & 34.1 & 12.50 & 5.60 \\
\hline & & $60-130$ & 1.90 & 40.3 & 10.90 & 4.70 \\
\hline \multirow{3}{*}{$\begin{array}{c}\text { Wadi } \\
\text { bottom }\end{array}$} & \multirow{3}{*}{3} & $0-25$ & 1.70 & 35.4 & 22.80 & 9.55 \\
\hline & & $25-70$ & 1.81 & 20.6 & 20.90 & 8.85 \\
\hline & & $70-140$ & 1.81 & 18.9 & 21.50 & 6.90 \\
\hline \multirow{9}{*}{$\begin{array}{l}\text { Rubble } \\
\text { terraces }\end{array}$} & \multirow{3}{*}{4} & $0-25$ & 1.33 & 51.1 & 3.50 & 14.70 \\
\hline & & $25-65$ & 1.35 & 49.9 & 3.20 & 17.30 \\
\hline & & $65-130$ & 1.25 & 50.9 & 1.80 & 18.90 \\
\hline & \multirow{3}{*}{5} & $0-35$ & 1.35 & 50.5 & 2.60 & 15.40 \\
\hline & & $35-75$ & 1.22 & 55.7 & 2.20 & 17.40 \\
\hline & & $75-140$ & 1.55 & 35.5 & 5.90 & 6.80 \\
\hline & \multirow{3}{*}{6} & $0-40$ & 1.85 & 39.9 & 7.90 & 7.00 \\
\hline & & $40-80$ & 1.85 & 38.8 & 6.50 & 6.10 \\
\hline & & $80-150$ & 1.61 & 40.1 & 8.50 & 5.00 \\
\hline \multirow{9}{*}{ Alluvial fan } & \multirow{3}{*}{7} & $0-25$ & 1.40 & 50.8 & 3.50 & 17.60 \\
\hline & & $25-65$ & 1.53 & 45.9 & 2.40 & 16.50 \\
\hline & & $65-125$ & 1.35 & 45.8 & 5.60 & 8.90 \\
\hline & \multirow{3}{*}{8} & 0.35 & 1.40 & 53.2 & 2.65 & 15.30 \\
\hline & & $35-80$ & 1.28 & 57.1 & 2.52 & 20.70 \\
\hline & & $80-150$ & 1.05 & 58.5 & 0.94 & 21.00 \\
\hline & \multirow{3}{*}{9} & 0.20 & 1.25 & 47.5 & 1.92 & 19.80 \\
\hline & & $20-60$ & 1.21 & 50.5 & 1.46 & 18.60 \\
\hline & & 60.120 & 1.19 & 49.2 & 1.33 & 16.10 \\
\hline \multirow{3}{*}{$\begin{array}{c}\text { River } \\
\text { terraces }\end{array}$} & \multirow{3}{*}{10} & $0-40$ & 1.15 & 60.4 & 1.35 & 21.80 \\
\hline & & $40-80$ & 1.22 & 61.1 & 2.60 & 18.00 \\
\hline & & $80-150$ & 1.31 & 49.3 & 1.92 & 17.00 \\
\hline
\end{tabular}

\section{b. Soils of Rubble terraces:}

These soils occupy wide areas and extend about $20 \mathrm{~km}$ in length with a width ranging between 2 and $4 \mathrm{~km}$ along both Wadi rims. Soil surface is mainly flat-gently undulating and covered with desert pavement, Aeolian and alluvial deposits. This unit is represented by profiles 4, 5 and 6. Data presented in Table (2) revealed that soil texture is restated to four textural classes of sandy, loamy sand, loamy and clay loam, in general, each one occupied partly zones of the studied soil profiles. $\mathrm{CaCO}_{3}$ content widely varied from 1.2 to $28.1 \%$. Meanwhile, organic matter content is very low, where its values ranged $0.10-0.30 \%$, reflecting the hyper arid climatic conditions of the area and the absence of natural vegetation cover. As for cation exchange capacity, which is more related to the soil textural class, the CEC values revealed that some soil sediments are clay enriched vs ones are poorer with a corresponding range of $20.6-4.0 \mathrm{c}$ molc kg-1 soil. In general, the exchangeable sodium percentage (ESP) fluctuated from 3.5 to $13.5 \%$, indicate that the soils of Rubble terraces are non-sodic ones.

Fayoum J. Agric. Res. \& Dev., Vol.24, No.1, January, 2010 
Table (4): Chemical analysis of the soil paste extract of the studied soil profiles.

\begin{tabular}{|c|c|c|c|c|c|c|c|c|c|c|c|c|}
\hline \multirow{3}{*}{$\begin{array}{l}\text { Land- } \\
\text { form }\end{array}$} & \multirow{3}{*}{$\begin{array}{l}\dot{0} \\
\dot{0} \\
\dot{0} \\
0 \\
0\end{array}$} & \multirow{3}{*}{ 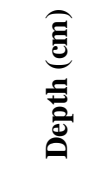 } & \multirow{3}{*}{ 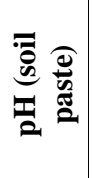 } & \multirow{3}{*}{ 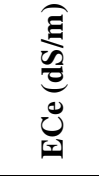 } & \multicolumn{8}{|c|}{ Soluble ions $\left(\mathrm{m}\right.$ molc $\left.\mathrm{L}^{-1}\right)$} \\
\hline & & & & & \multicolumn{4}{|c|}{ Cations } & \multicolumn{4}{|c|}{ Anions } \\
\hline & & & & & $\mathrm{Ca}^{++}$ & $\mathbf{M g}^{++}$ & $\mathrm{Na}^{+}$ & $\mathbf{K}^{+}$ & $\mathrm{CO}_{3}^{--}$ & $\mathrm{HCO}_{3}^{-}$ & $\mathrm{CI}^{-}$ & $\mathrm{SO}_{4}{ }^{--}$ \\
\hline \multirow{6}{*}{$\begin{array}{l}\text { Wadi } \\
\text { plain }\end{array}$} & \multirow{3}{*}{1} & $0-30$ & 7.8 & 11.49 & 46.20 & 11.10 & 56.87 & 1.92 & 0.00 & 3.00 & 51.00 & 62.09 \\
\hline & & $30-80$ & 7.9 & 22.70 & 125.4 & 33.10 & 113.9 & 1.50 & 0.00 & 1.80 & 110.0 & 162.1 \\
\hline & & $80-120$ & 8.2 & 37.20 & 250.0 & 37.00 & 271.1 & 2.00 & 0.00 & 2.00 & 290.0 & 267.1 \\
\hline & \multirow{3}{*}{2} & $0-35$ & 7.8 & 2.78 & 9.30 & 3.70 & 14.58 & 0.27 & 0.00 & 2.00 & 4.00 & 11.85 \\
\hline & & $35-60$ & 8.1 & 2.35 & 8.60 & 5.70 & 9.60 & 0.20 & 00 & 2.00 & 11.00 & .10 \\
\hline & & $60-130$ & 8.1 & 5.30 & 13.40 & 7.10 & 30.56 & 0.95 & 00 & 2.60 & .50 & 1.91 \\
\hline \multirow{3}{*}{$\begin{array}{c}\text { Wadi } \\
\text { bottom }\end{array}$} & \multirow{3}{*}{3} & $0-25$ & 7.9 & 9.68 & 35.10 & 6.20 & 56.95 & 1.37 & 0.00 & 2.50 & 5.00 & 42.12 \\
\hline & & $25-70$ & 8.0 & 12.00 & 53.20 & 25.80 & 53.00 & 1.88 & 0.00 & 2.40 & 55.00 & 76.48 \\
\hline & & $70-140$ & 8.1 & 9.68 & 35.10 & 6.20 & 56.95 & 1.37 & 0.00 & 2.50 & 55.00 & 42.12 \\
\hline \multirow{9}{*}{$\begin{array}{l}\text { Rubble } \\
\text { terraces }\end{array}$} & \multirow{3}{*}{4} & $0-25$ & 7.8 & 4.04 & 17.50 & 4.50 & 19.17 & 0.30 & 0.00 & 1.20 & 17.50 & 22.77 \\
\hline & & $25-65$ & 7.9 & 4.95 & 21.20 & 5.10 & 25.80 & 1.96 & 0.00 & 2.30 & 25.00 & 26.76 \\
\hline & & $65-130$ & 8.1 & 6.15 & 19.20 & 6.50 & 33.50 & 1.36 & 0.00 & 2.00 & 30.00 & 28.56 \\
\hline & \multirow{3}{*}{5} & $0-35$ & 8.0 & 1.35 & 7.20 & 4.20 & 3.50 & 0.25 & 0.00 & 2.30 & 2.50 & 10.35 \\
\hline & & $35-75$ & 8.1 & 0.55 & 2.40 & & 90 & & & 2.80 & 1.50 & 1.50 \\
\hline & & $75-140$ & 8.2 & 1.28 & 6.10 & 2.90 & 4.50 & & 80 & 2.00 & 5.50 & 7.27 \\
\hline & \multirow{3}{*}{6} & $0-40$ & 7.6 & 2.40 & 9.20 & 2.80 & 13.75 & 0.27 & 0.00 & 1.40 & 11.50 & 13.12 \\
\hline & & $40-80$ & 7.7 & 4.55 & 17.40 & 6.00 & 22.20 & 0.75 & 0.00 & 1.80 & 25.00 & 19.53 \\
\hline & & $80-150$ & 7.8 & 6.13 & 19.20 & 6.50 & 33.50 & 1.36 & 0.00 & 2.00 & 30.00 & 28.56 \\
\hline \multirow{9}{*}{$\begin{array}{l}\text { Alluvial } \\
\text { fan }\end{array}$} & \multirow{3}{*}{7} & $0-25$ & 8.1 & 7.70 & 33.20 & 4.80 & 39.57 & 1.13 & 0.00 & 1.20 & 44.00 & 33.50 \\
\hline & & $25-65$ & 8.2 & 2.60 & 4.60 & 3.60 & 18.11 & 0.30 & 0.00 & 2.40 & 15.00 & 9.21 \\
\hline & & $65-125$ & 8.3 & 3.90 & 9.40 & 7.10 & 22.67 & 0.91 & 0.00 & 2.30 & 22.50 & 15.28 \\
\hline & \multirow{3}{*}{8} & 0.35 & 7.6 & 14.30 & 52.80 & 11.20 & 96.75 & 2.05 & 0.00 & 2.60 & 94.00 & 66.20 \\
\hline & & $35-80$ & 7.7 & 18.30 & 71.40 & 12.60 & 116.5 & 1.38 & 0.00 & 2.00 & 124.0 & 75.88 \\
\hline & & $80-150$ & 7.9 & 19.50 & 75.20 & 10.80 & 114.5 & 1.60 & 0.00 & 2.00 & 121.5 & 78.60 \\
\hline & \multirow{3}{*}{9} & 0.20 & 8.0 & 3.45 & 8.60 & 6.40 & 19.10 & 1.18 & 0.00 & 1.20 & 17.50 & 16.58 \\
\hline & & $20-60$ & 8.2 & 1.60 & 7.60 & 2.40 & 7.48 & 0.33 & 0.00 & 1.80 & 6.50 & 9.51 \\
\hline & & 60.120 & 8.3 & 4.20 & 19.20 & 7.80 & 14.80 & 0.25 & 0.00 & 2.20 & 185.0 & 21.35 \\
\hline \multirow{3}{*}{$\begin{array}{l}\text { River } \\
\text { terraces }\end{array}$} & \multirow{3}{*}{10} & $0-40$ & 8.1 & 1.83 & 7.60 & 4.50 & 7.48 & 0.97 & 0.00 & 2.20 & 7.00 & 11.35 \\
\hline & & $40-80$ & 8.2 & 3.73 & 14.40 & 6.05 & 16.67 & 1.05 & 0.00 & 2.00 & 19.00 & 17.17 \\
\hline & & $80-150$ & 8.4 & 2.68 & 9.00 & 4.20 & 13.70 & 0.50 & 0.00 & 1.50 & 11.50 & 14.40 \\
\hline
\end{tabular}

Values of bulk density, Table (3), ranged $1.25-1.85 \mathrm{~g} \mathrm{~cm}^{-3}$, the highest value is associated with the coarse texture soil (sandy), while the lowest value ( $1.22 \mathrm{~g}$ $\mathrm{cm}^{-3}$ ) is detected in the texture grade of soil profile No. 5. The later case is expected, since the fine textured soil has more greatly developed structure which causes a decrease largely soil bulk density value. Total porosity is an index of the relative volume of pores in the soil, accordingly, its values for the representative soil sites are widely varied from 35.5 to $55.7 \%$, where the later value represents the relatively fine textured soil.

Soil hydraulic conductivity, Table (3), which measures the rate of downward movement of water by gravity, revealed that it values ranged 1.8-8.5 $\mathrm{cm} / \mathrm{h}$. The lowest value is found in the relatively fine textured soil (clay loam of soil profile No. 4), while the highest one represents the relatively coarse textured soil (sandy of soil profile No. 6). The later case may be due to the occurrence of highest percentage of quickly drainable pores between the dominant coarse sand particles which entails increasing hydraulic conductivity. On the contrary, the

Fayoum J. Agric. Res. \& Dev., Vol.24, No.1, January, 2010 


\section{PEDOLOGICAL STUDIES ON THE SOILS OF WADI EL-ASYUTI,..114}

increase in soil clay contents leads to increase in the percentage of fine capillary pores, and consequently decrease the hydraulic conductivity.

From the data presented in Table (3), it can be noticed that soil available moisture content, which dictates the percentages of retained moisture on volume bases, tended to increase by increasing the finer fractions which if present they are mostly of inactive finely distigrated coarse texture class. The obtained data indicated that soil available moisture values range 5.0-18.9\%, where the lowest value (soil profile No. 6) is rendered to the low energy of water retention on soil particles due to the low specific surface of the coarse textured sediments. The relatively high content of soil available moisture, as shown in soil profile No. 4 , is more attributed to the presence of certain clay minerals that have a quite high specific surface area to retain moisture.

Data presented in Table (4) revealed that Rubble terraces soils are almost neutral to moderately alkaline, where soil $\mathrm{pH}$ value ranged from 7.6 to 8.1 . The ECe values indicated that the soils are non-saline to slightly saline as defined by ECe values which ranged from 0.55 to $6.15 \mathrm{dSm}^{-1}$. Soluble cations are dominated by $\mathrm{Ca}^{++}$and/or $\mathrm{Na}^{+}$followed by $\mathrm{Mg}^{++}$and $\mathrm{K}^{+}$vs soluble anions dominated by $\mathrm{SO}_{4}{ }^{2-}$ and/or $\mathrm{Cl}^{-}$, while $\mathrm{HCO}_{3}{ }^{-}$represents the least abundant soluble anions.

\section{c. Soils of Alluvial fan:}

The soils of the Alluvial fan unit are generally, almost flat to gently undulating. They occupy a relatively large area covered with some rock fragments of different sizes. The soils are mainly affected by both past and current erosional processes with different degrees. These soils are represented by soil profile Nos. 7, 8 and 9, which are characterized by soil texture lies in the classes of sandy loam-silty clay loam, a wide range of $\mathrm{CaCO}_{3}$ content (2.1-39.5\%). Also, a pronounced of 12.5-20.9\% with an irregular distribution pattern with depth was occurred. Also, an extremely low content of organic matter $(0.30-0.90 \%)$ was detected owing to the prevailing aridity in the region and its scattered natural vegetation. Accordingly, the CEC is rather relatively low due to the nature of relatively coarse texture grade, where its values fluctuate between 7.1 and $32.5 \mathrm{c}$ molc $\mathrm{kg}^{-1}$ soil as well as ESP value ranged 2.9-14.5\% indicating non-sodic soils, as shown in Table (2).

Data in Table (3) indicated that soil bulk density, total porosity, hydraulic conductivity and available moisture range values that depend on both soil texture and structure are varied widely between $1.05-1.40 \mathrm{~g} \mathrm{~cm}^{-3}, 45.8-58.5 \%, 0.94-5.60$ $\mathrm{cm} \mathrm{h}^{-1}$ and 8.9-21.0\%, respectively. In addition, the chemical composition of the soil paste and its extract, Table (4), showed that soil reaction $(\mathrm{pH})$ tends towards mildly alkaline (7.6-8.3) and ECe values of 1.6-19.5 $\mathrm{dSm}^{-1}$, i.e., non-saline to strongly saline soils. The cationic composition are dominated by $\mathrm{Na}^{+}$followed by $\mathrm{Ca}^{++}$and $\mathrm{Mg}^{++}$, while $\mathrm{K}^{=}$ion represents the least abundant vs an anionic pattern dominated by $\mathrm{Cl}^{-}$followed by $\mathrm{SO}_{4}{ }^{2-}$ and $\mathrm{HCO}_{3}{ }^{-}$.

\section{d. Soils of River terraces:}

This landform unit occupies remnants of the old Nile deposits (fluvial soils during a Sabilian period), and its soils are represented by soil profile No. 10, which its surface is characterized by almost flat. Also, this unit is extending along the eastern part of the cultivated area of the Nile Valley. Analytical data that are

Fayoum J. Agric. Res. \& Dev., Vol.24, No.1, January, 2010 
given in Table (2) showed that the representative soil site comprises by an interference zone of fluvial-colluvial sediments, with narrow different soil texture grades, i.e., loamy-clay loam. In general, the values of $\mathrm{CaCO}_{3}$, organic matter, CEC and ESP, Table (2), widely varied from 13.9-32.2, 0.34-0.70 \%, 12.6-15.5 c molc $\mathrm{kg}^{-1}$ soil and 3.9-5.3\%, respectively. Such data are reflecting the medium soil textural grade, calcareous in nature, either hyper arid climatic conditions of the area or the absence of natural vegetation cover and cation exchange capacity more related to the soil textural class, with a non-sodic condition.

Values of bulk density, total porosity, hydraulic conductivity and available moisture ranged between $1.15-1.31 \mathrm{~g} \mathrm{~cm}^{-3}, 49.3-61.1 \%, 1.35-2.60 \mathrm{~cm} \mathrm{~h}^{-1}$ and 17.0-21.8\%, respectively. These favourable soil conditions are expected, since the relatively fine textured soil grade has more greatly developed structure, which causes a decrease largely soil bulk density value vs a relatively higher total porosity, however, it is an index of the relative volume of pores in the soil. Soil hydraulic conductivity value was relatively low, mainly due to the relatively fine textured soil (clay loam), and in turn a pronounced increase in the percentage of fine capillary pores, and consequently decrease the hydraulic conductivity. The reverse was true for soil available moisture content, which dictates the percentages of retained moisture on volume bases, tended to increase by increasing the finer fractions.

Data presented in Table (4) revealed that River Nile terraces soils tended towards alkaline side (soil $\mathrm{pH} \approx 8.1-8.4$ ), non-saline condition, $(\mathrm{ECe} \approx 1.83-3.73$ $\mathrm{dSm}^{-1}$ ) and soluble cations are arranged in an ascending order of $\mathrm{Na}^{+}>\mathrm{Ca}^{2+}>$ $\mathrm{Mg}^{2+}>\mathrm{K}^{+}$vs anions dominated by $\mathrm{Cl}^{-}$and/or $\mathrm{SO}_{4}{ }^{2-}$, while $\mathrm{HCO}_{3}{ }^{-}$represents the least abundant soluble anions.

In conclusion, it is quite clear that the retained soil moisture for coarse textured soils is more related with coatings of either colloidal secondary carbonates or free iron oxides which retain more water relative to uncoated quartz grains. In contrast, soils of Alluvial fan, Rubble and River terraces containing appreciable amounts of fine fractions retain more moisture if compared with those non-calcareous having correspondent textures. This can be explained on the premise that $\mathrm{CaCO}_{3}$ content which is high in the fine fraction that is responsible for such diminution of water retention.

\section{Origin of soil parent materials:}

Certain statistical size parameters are often taken as indices for either origin of soil materials or their deposition mode. The statistical size parameters, i.e., median diameter (Md), sorting (So) and Skeweness (SK) are calculated as described by Pettijohn (1957) and given in Table (5). Accordingly, the relationships between the statistical size parameters and either soil origin or its deposition mode among the studied soil sites profiles could be interpreted as follows. Soils that are represented by soil profile Nos. 1, 2 (Wadi plain unit) and 6 (Rubble terraces unit) are poorly sorted sediments in all the profiles layers, except of some profile layers that are moderately sorted sediments. That means these soils are mostly transported and deposited under water action, i.e., aqueous media for the poorly sorted sediments as well as dual actions of water-wind (aqueousaeolian deposits) for the moderately sorted sediments.

Fayoum J. Agric. Res. \& Dev., Vol.24, No.1, January, 2010 
PEDOLOGICAL STUDIES ON THE SOILS OF WADI EL-ASYUTI,...116

Table (5): Statistical size parameters of the studied soil profiles.

\begin{tabular}{|c|c|c|c|c|c|c|c|c|c|c|}
\hline \multirow{2}{*}{$\begin{array}{l}\text { Land- } \\
\text { form }\end{array}$} & \multirow{2}{*}{ 这 } & \multirow{2}{*}{$\begin{array}{c}\text { Depth } \\
\text { (em ) }\end{array}$} & \multirow[b]{2}{*}{$\mathbf{Q}_{1}$} & \multirow[b]{2}{*}{$\mathbf{M}_{\mathbf{j}}$} & \multirow[b]{2}{*}{$\mathbf{Q}_{3}$} & \multirow[b]{2}{*}{ So } & \multirow[b]{2}{*}{ So index } & \multirow[b]{2}{*}{ Sk } & \multicolumn{2}{|c|}{ Log Sk index } \\
\hline & & & & & & & & & Value & $\begin{array}{c}\text { Skewed } \\
\text { index }\end{array}$ \\
\hline \multirow{6}{*}{$\begin{array}{l}\text { Wadi } \\
\text { plain }\end{array}$} & \multirow{3}{*}{1} & $0-30$ & 32 & 100 & 400 & 9.4 & Poorly sorted & 1.13 & +0.053 & Fine \\
\hline & & $30-80$ & 35 & 160 & 600 & 17.1 & Poorly sorted & 0.9206 & -0.043 & Coarse \\
\hline & & $80-120$ & 260 & 520 & 1000 & 3.8 & Moderately sorted & 0.981 & -0.009 & Coarse \\
\hline & \multirow{3}{*}{2} & $0-35$ & 240 & 450 & 990 & 4.1 & Moderately sorted & 1.0832 & +0.035 & Fine \\
\hline & & $35-60$ & 52 & 140 & 500 & 9.6 & Poorly sorted & 1.1518 & +0.061 & Fine \\
\hline & & $60-130$ & 50 & 120 & 400 & 8.0 & Poorly sorted & 1.1785 & +0.071 & Fine \\
\hline \multirow{3}{*}{$\begin{array}{l}\text { Wadi } \\
\text { bottom }\end{array}$} & \multirow{3}{*}{3} & $0-25$ & 38 & 100 & 390 & 10.3 & Poorly sorted & 1.2174 & +0.085 & Fine \\
\hline & & $25-70$ & 90 & 350 & 800 & 8.9 & Poorly sorted & 0.7667 & +0.115 & Coarse \\
\hline & & $70-140$ & 60 & 300 & 790 & 13.2 & Poorly sorted & 0.7257 & -0.139 & Coarse \\
\hline \multirow{9}{*}{$\begin{array}{l}\text { Rubble } \\
\text { terraces }\end{array}$} & \multirow{3}{*}{4} & $0-25$ & 3.5 & 16 & 120 & 34.3 & Poorly sorted & 1.2809 & +0.108 & Fine \\
\hline & & $25-65$ & - & 10 & 80 & - & - & - & - & - \\
\hline & & $65-130$ & - & 8 & 60 & - & - & - & - & - \\
\hline & \multirow{3}{*}{5} & $0-35$ & 3.5 & 16 & 120 & 34.3 & Poorly sorted & 1.3636 & -0.134 & Fine \\
\hline & & $35-75$ & - & 9 & 50 & - & - & - & - & - \\
\hline & & $75-140$ & 60 & 270 & 700 & 11.7 & Poorly sorted & 0.7590 & -0.120 & Coarse \\
\hline & \multirow{3}{*}{6} & $0-40$ & 40 & 200 & 640 & 16.0 & Poorly sorted & 0.80 & -0.097 & Coarse \\
\hline & & $40-80$ & 230 & 430 & 950 & 4.1 & Moderately sorted & 1.0871 & +0.036 & Fine \\
\hline & & $80-150$ & 230 & 430 & 1000 & 4.3 & Moderately sorted & 1.1153 & +0.047 & Fine \\
\hline \multirow{9}{*}{$\begin{array}{l}\text { Alluvial } \\
\text { fan }\end{array}$} & \multirow{3}{*}{7} & $0-25$ & 2.5 & 11 & 80 & 32.0 & Poorly sorted & 1.2856 & & Fine \\
\hline & & $25-65$ & 2.3 & 8 & 36 & 15.7 & Poorly sorted & 1.1374 & & Fine \\
\hline & & $65-125$ & 20 & 50 & 120 & 6.0 & Poorly sorted & 0.9798 & & Coarse \\
\hline & \multirow{3}{*}{8} & 0.35 & - & 9 & 62 & - & - & - & - & - \\
\hline & & $35-80$ & - & 4.5 & 16 & - & - & - & - & - \\
\hline & & $80-150$ & - & 3.5 & 11 & - & - & - & - & - \\
\hline & \multirow{3}{*}{9} & 0.20 & 2.1 & 7 & 50 & 23.8 & Poorly sorted & 1.4639 & & Fine \\
\hline & & $20-60$ & - & 7 & 25 & - & - & & & - \\
\hline & & 60.120 & 2.7 & 14 & 130 & 48.1 & Poorly sorted & 13382 & & Fine \\
\hline \multirow{3}{*}{$\begin{array}{c}\text { River } \\
\text { terraces- }\end{array}$} & \multirow{3}{*}{10} & $0-40$ & - & 5 & 16 & - & - & - & - & - \\
\hline & & $40-80$ & 2.4 & 10 & 61 & 25.4 & Poorly sorted & 1.2099 & & Fine \\
\hline & & $80-150$ & 2.1 & 10 & 7.1 & 33.8 & Poorly sorted & 0.4583 & & Coarse \\
\hline
\end{tabular}

Meanwhile, soils of profile Nos. 3 (Wadi bottom unit), 4 (Rubble terraces unit), 7, 8, 9 (alluvial fan unit) and 10 (River terraces unit) were fully transported and deposited by water action (aqueous media), due to these soils are characterized by poorly sorted sediments and fine to coarse skewed.

From the above mentioned results, it is clear that water action is considered the predominating agent for transportation and deposition for the majority of soil sediments (aqueous media) of Wadi El-Asyuti, due to the poorly sorted conditions and partly dual actions of water-wind (aqueous-aeolian deposits) for the moderately sorted ones in some profile layers at few soil sites under study.

Fayoum J. Agric. Res. \& Dev., Vol.24, No.1, January, 2010 


\section{Mineralogy of the sand fraction:}

The mineralogical composition of the sand fraction sized $0.063-0.125 \mathrm{~mm}$ plays an important role in order to evaluate the soil genesis and uniformity for Wadi El-Asyuti area, however, heavy mineral contents and their assemblage are conducted, as shown in Table (6). The frequency distribution of heavy minerals indicates that opaque minerals besides pyroxenes and amphiboles are the most abundant heavy minerals.

Table (6): Frequency distribution of heavy minerals in the sand fraction sized 0.125$0.063 \mathrm{~mm}$ and uniformity ratios of the representative soil profiles.

\begin{tabular}{|c|c|c|c|c|c|c|c|c|c|c|c|c|c|c|c|c|c|}
\hline \multirow{3}{*}{$\begin{array}{l}\dot{0} \\
\dot{z} \\
\dot{0} \\
\dot{0} \\
\dot{2}\end{array}$} & \multirow{3}{*}{ 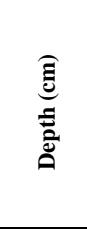 } & \multirow{3}{*}{ 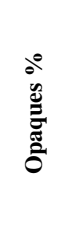 } & \multicolumn{12}{|c|}{ Non-opaques \% } & \multirow{2}{*}{\multicolumn{3}{|c|}{ Uniformity ratios }} \\
\hline & & & \multirow{2}{*}{ 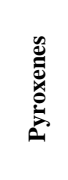 } & \multirow{2}{*}{ 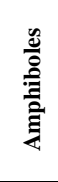 } & \multicolumn{4}{|c|}{ Parametamorphic } & \multicolumn{4}{|c|}{ Ubibuitous } & \multirow[b]{2}{*}{ 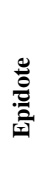 } & \multirow[b]{2}{*}{ 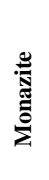 } & & & \\
\hline & & & & & 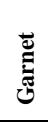 & 苛 & 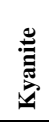 & 䒿 & 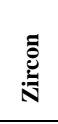 & 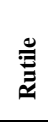 & 总 & : & & & $\stackrel{\Re}{\stackrel{\Lambda}{N}}$ & S & $\stackrel{+}{+}$ \\
\hline \multirow{3}{*}{1} & $0-30$ & 46.9 & 42.5 & 14.3 & 6.9 & 2.7 & 2.8 & 0.5 & 10.4 & 4.2 & 7.1 & 0.5 & 2.2 & 5.1 & 2.4 & 1.5 & 0.9 \\
\hline & $30-80$ & 47.7 & 45.9 & 17.6 & 3.3 & 4.5 & 2.5 & 0.1 & 6.5 & 5.5 & 5.9 & 2.6 & 1.8 & 3.7 & 1.2 & 1.1 & 0.6 \\
\hline & $80-120$ & 55.5 & 51.1 & 20.9 & 2.1 & 2.2 & 1.7 & 0.1 & 6.9 & 2.2 & 4.2 & 4.1 & 1.1 & 2.8 & 3.1 & 1.6 & 1.1 \\
\hline \multirow{3}{*}{3} & $0-25$ & 36.3 & 50.2 & 31.2 & 2.9 & 1.4 & 2.3 & -- & 4.1 & 1.5 & 1.1 & 1.4 & 1.7 & 2.5 & 2.7 & 3.7 & 1.6 \\
\hline & $25-70$ & 45.3 & 40.9 & 33.1 & 4.5 & 3.3 & 1.9 & -- & 6.9 & 3.8 & 1.5 & 0.9 & 1.9 & 1.9 & 1.8 & 4.6 & 1.3 \\
\hline & 70140 & 46.5 & 40.6 & 31.9 & 5.1 & 2.3 & 0.8 & -- & 7.7 & 2.5 & 2.1 & 1.3 & 3.5 & 2.5 & 3.1 & 3.7 & 1.7 \\
\hline \multirow{3}{*}{4} & $0-25$ & 28.1 & 46.8 & 35.5 & 2.3 & 1.9 & 3.2 & -- & 5.6 & 2.1 & 0.5 & 0.6 & 1.4 & 0.5 & 2.7 & 11.2 & 2.2 \\
\hline & $25-65$ & 30.4 & 48.7 & 26.7 & 2.1 & 0.6 & 1.5 & -- & 6.9 & 4.8 & 1.5 & 2.9 & 2.9 & 1.7 & 1.4 & 4.6 & 1.1 \\
\hline & $65-130$ & 32.5 & 42.9 & 27.7 & 3.3 & 2.3 & 0.8 & -- & 9.8 & 6.6 & 1.8 & 1.9 & 1.6 & 2.1 & 1.5 & 5.4 & 1.2 \\
\hline \multirow{3}{*}{6} & $0-40$ & 40.2 & 44.8 & 25.2 & 4.1 & 2.9 & 2.5 & -- & 10.7 & 2.7 & 1.6 & 0.5 & 2.9 & 1.9 & 3.9 & 6.7 & 2.5 \\
\hline & $40-80$ & 25.1 & 49.2 & 32.6 & 3.5 & 1.1 & 1.9 & -- & 4.8 & 0.6 & 1.6 & 1.3 & 1.3 & 1.9 & 8.0 & 3.0 & 2.2 \\
\hline & $80-150$ & 30.2 & 46.5 & 20.9 & 5.9 & 3.1 & 3.1 & -- & 8.2 & 3.3 & 2.3 & 2.3 & 2.9 & 1.8 & 2.5 & 3.7 & 1.5 \\
\hline \multirow{3}{*}{8} & $0-35$ & 58.2 & 32.9 & 18.1 & 3.9 & 5.7 & 2.5 & -- & 12.1 & 8.5 & 5.7 & 3.8 & 2.6 & 4.6 & 1.4 & 2.1 & 0.9 \\
\hline & $35-80$ & 47.9 & 42.7 & 24.4 & 4.9 & 2.8 & 2.9 & 0.5 & 9.1 & 2.6 & 3.9 & 1.9 & 1.9 & 4.7 & 3.5 & 2.3 & 1.4 \\
\hline & $80-150$ & 48.7 & 41.4 & 24.2 & 3.5 & 3.7 & 3.2 & 1.1 & 10.9 & 8.1 & 6.2 & 0.9 & 1.9 & 5.3 & 1.3 & 1.8 & 0.8 \\
\hline \multirow{3}{*}{10} & $0-40$ & 50.8 & 42.1 & 10.7 & 5.9 & 4.7 & 2.5 & -- & 13.4 & 9.4 & 2.9 & 2.5 & 3.4 & 2.6 & 1.4 & 4.6 & 1.1 \\
\hline & $40-80$ & 54.6 & 45.2 & 19.1 & 4.7 & 3.2 & 4.9 & 1.3 & 8.7 & 2.4 & 3.5 & 1.3 & 1.3 & 5.4 & 3.6 & 2.5 & 1.5 \\
\hline & $80-150$ & 59.6 & 40.6 & 16.5 & 3.4 & 4.4 & 2.3 & -- & 10.1 & 7.1 & 6.1 & 2.9 & 2.9 & 3.5 & 1.4 & 1.7 & 0.8 \\
\hline
\end{tabular}

Also, zircon, garnet and rutile minerals are present in relatively moderate amounts, while the remaining minerals are detected in less pronounced amounts. The wide variations of the heavy minerals are mainly attributed to the different geological origins of soil parent materials as well as to the strength and intensity of weathering processes, erosion, transportation and deposition which have a considerable influence on the relative proportions of heavy minerals in the soils under study.

From the heavy minerals association and characteristics, it is evident that the studied soils are relatively recent formed due to they exhibit a weakly developed in nature. The later phenomenon is emphasized by the abundance of pyroxenes and amphiboles which are considered to be less stable minerals.

Using the mineralogical composition as a guide for evaluating the homogeneity or heterogeneity phases of soil parent materials could be established on the assumption that certain heavy minerals are more resistant to weathering, thus their diminish during the course of soil development. In this connection, the ratios of ultra stable resistant minerals $(\mathrm{Zr} \approx$ Zircon, $\mathrm{T} \approx$ Tourmaline and $\mathrm{R} \approx$ Rutile) to weathering, i.e., $\mathrm{Zr} / \mathrm{T}, \mathrm{Zn} / \mathrm{R}$ and $\mathrm{Zr} / \mathrm{T}+\mathrm{R}$ are taken as criteria for evaluating soil profile uniformity and weathering sequence for the soil sediments, Table (6). The obtained data of uniformity ratios showed that most of the studied

Fayoum J. Agric. Res. \& Dev., Vol.24, No.1, January, 2010 
PEDOLOGICAL STUDIES ON THE SOILS OF WADI EL-ASYUTI,... 118 soils of Wadi El-Asyuti have a state of stratification and heterogeneity of their parent materials. This may be the results of the contamination of more than one sediment or suggests the multi-depositional regime of these soils.

\section{REFERECNCES:}

Abu-Al-Izz M.S. (1971). Landforms of Egypt. The Am. Univ., Cairo Press, Egypt, 282 pp.

Baver, L.D. (1963). Soil Physics. $3^{\text {rd }}$, Ed., John Wiley \& Sons Inc., New York, USA.

Brewer, R. (1964). Fabric and Mineral Analysis of Soils. John Wiley and Sons Inc., New York, USA.

FAO (1990). Guidelines for Soil Profile Description. $3^{\text {rd }}$, Ed. (Revised), FAO, Rome, Italy.

Goosen, A.A.I. (1967). Aerial photo-interpretation in Soil Survey. Soil Bull. No. 6 , Rome, Italy.

HDSS (1964). The High Dam Soil Survey Project. Vol. II and III, FAO, Rome, Italy.

Jackson, M.L. (1965). Clay transformation in soil genesis during the Quaternary. Soil Sci., 99: 15-22.

Jackson, M.L. (1967). Soil Chemical Analysis. Constable and Co. LTD., London.

James, A.V. (1965). Porosity. Black, C.A. (Ed.), Methods of Soil Analyses. I: 299-314.

LMP (1986). Land Master Plan Project. Regional Report Upper Egypt, RPDA, Egypt.

Pettijohn, F.J. (1957). Sedimentary Rocks. New York, Harper and Brother.

Piper, C.S. (1950). Soil and Plant Analyses. Univ. of Adelaide Australia.

Richards, L.A. (1954): Diagnosis and Improvement of Saline and Alkali Soils. USDA Hand book No. 60, US. Govt. Printing Office, Washington, D.C., USA.

Said, R. (1962). The Geology of Egypt. El-Sevier Publ. Co., Amsterdam., New York.

Tucker, M.E. (1954). The determination of exchangeable calcium and magnesium in calcareous soils. Aust. J. Agric., RES, 706-715 pp.

USDA (1975). Soil Taxonomy. A Basic System of Soil Classification for Making and Interpretation of Soil Surveys. Agriculture Hand book No. 436. USDA, Washington, D.C., 20402.

Vomocil, J.A. (1965). Methods of Soils Analysis. Part. I, Edited by Black, C.A. Am. Soc. Agron. No. 9 Agric. 299-314, Madison, Wisconsin, USA.

Fayoum J. Agric. Res. \& Dev., Vol.24, No.1, January, 2010 


$$
\begin{aligned}
& \text { دراسات بيدولوجية على أراضي وادي الأسيوطي - الصحراء الشرقية ـ مصر } \\
& \text { سامي عبد الجيد عبد الله } \\
& \text { معهد بحوث الأر اضي و المياه و البيئة - مركز البحوث الزيل الزر اعية ـ جيزة - مصر }
\end{aligned}
$$

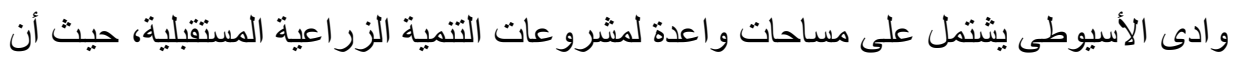

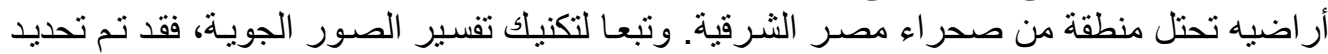

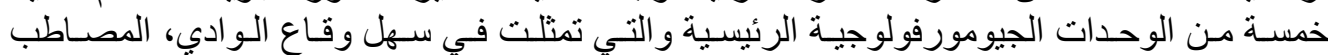

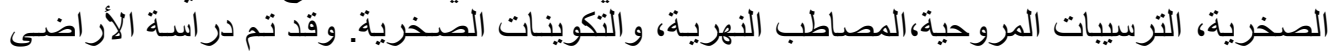
المتكونة على هذه الوحدات من خلال عشرة قطاعات أرضية أرضية ممثلة.

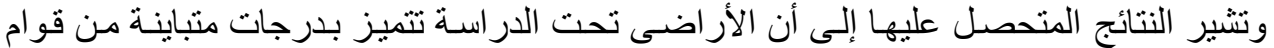

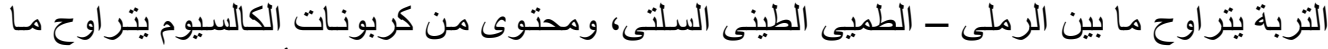

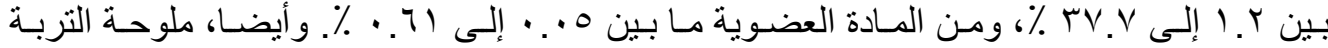

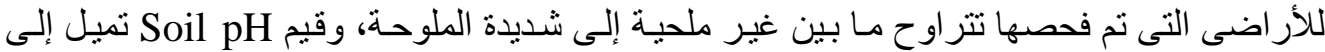

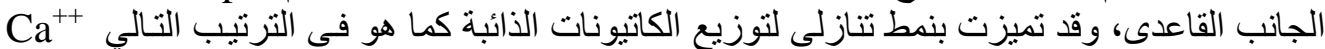

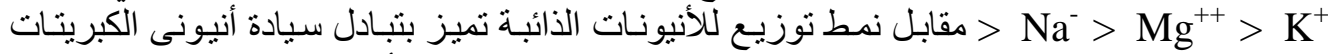

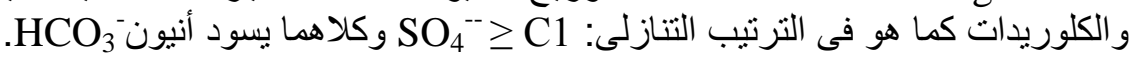

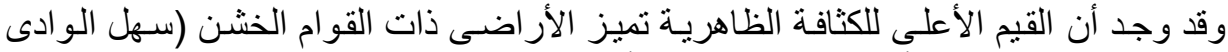

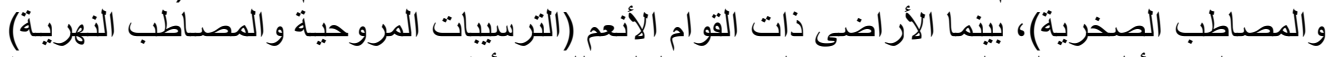

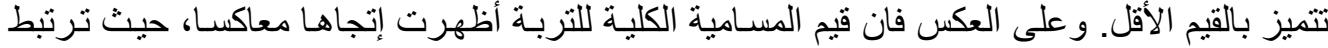

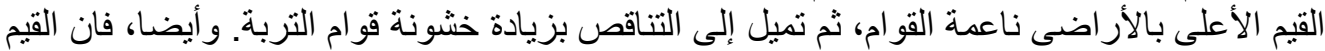

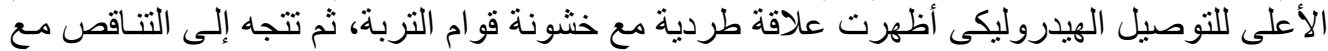

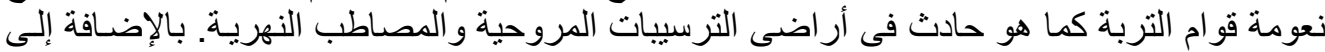

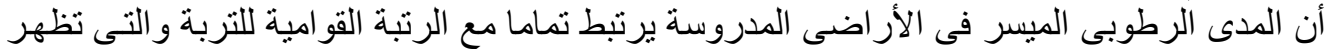

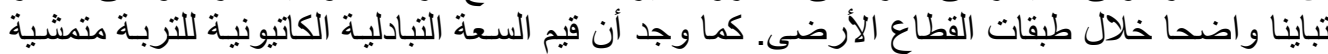

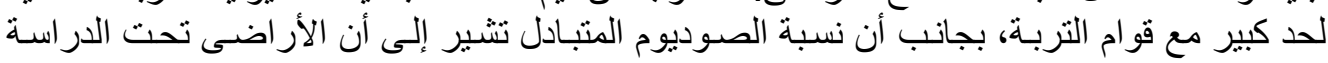

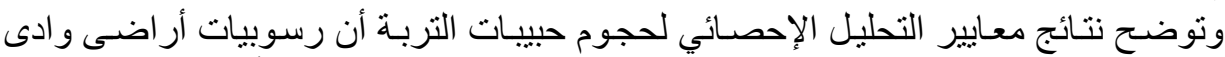
غير قلوية.

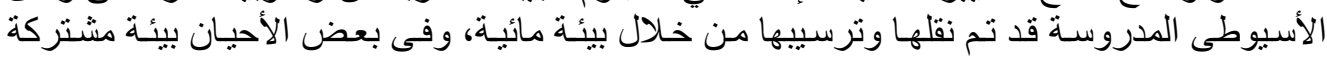

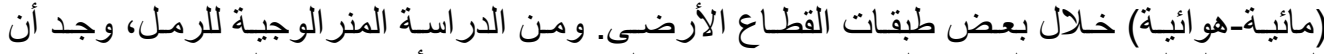

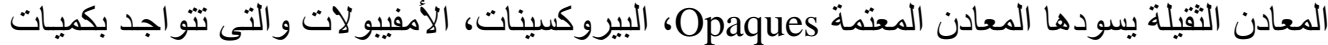

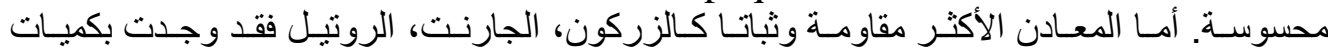

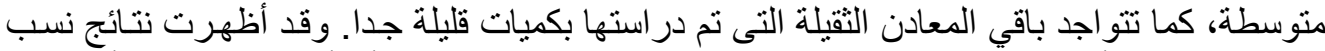

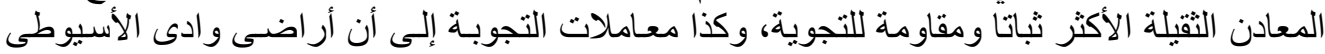

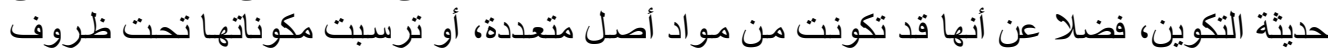

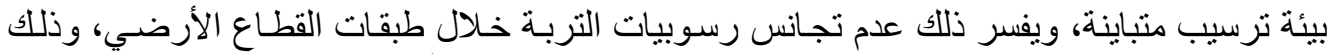
مرتبط لحد كبير بعمليات التجوية الموروثنة عن التكوين الجيولوجى أو الناتجـة مـن التجويـة الكيميائيسة وكلاهما مرتبط لحد كبير بأصل رسوبيات التربة المدروسة.

Fayoum J. Agric. Res. \& Dev., Vol.24, No.1, January, 2010 